\title{
RELATIONSHIP BETWEEN THE POPULATION DENSITY OF SILVER LEAF WHITEFLY Bemesia Argentifolii(BELLOWS AND PERRING) AND THE SPREAD OFSQUASH LEAF CURL VIRUS( SLCV )ON SQUASH LEAVES IN EGYPT \\ Abu El-Nagga, A. M. ; N. F. Abd El-Baky*; M. E. El- Naggar ${ }^{\star \star}$ and Gamila A. Heikal ${ }^{\star \star}$ \\ * Economic Entomology Dept.,Facultyof Agric., Mansoura University. ** Plant Protection Research Institute, A.R.C.,Dokki,Giza,Egypt.
}

\section{ABSTRACT}

During the study seasons 2004 and 2005, squash plant leaves were chosen to estimate the infestation of whitefly different stages and virus infection ratio in Dakahlia Governorate. This study was carried out to classify the natural infestation of the whitefly and associated virus infection ratio on squash leaves. The first appearance of the whitefly on summer plantation occurred during the late of April 2004 with low adult number and then gradually increased to reach the highest level of infestation during the mid of July of the same season and during early of August for nymphal stages However, the same trend of population was recorded in 2005 summer season but with different numbers recording the peak of abundance during the last week of August for adult stage and during the early of the same month for nymphal stages population. However, the regular inspection of squash leaves revealed that the early infestation of whitefly on squash leaves during Nili plantation was determined during the late of April 2004 and continuously increased till reaching to their maximum population level during mid of both July and August for adult stages. The population of whitefly nymphal stage was slightly lower than that of adult recording the peak of abundance during early of August. During 2005 Nili cultivation season, the adult and nymphal infestation of whitefly was obviously denoted that the population was in a gradually increased reaching to their highest level during late of August. Moreover, the virus infection ratio in this study during Nili plantation was recorded the highest ratio during early and mid of August 2004 and late of August 2005.The regular inspection of squash plantations during the different sowing times through the experiment revealed that the following periods Summer 2004, summer 2005 and summer 2006 were the preferable time for growing the population of the whitefly nymphs but the Nili 2004 and Nili 2005 were the lowest period for harboring the nymph population. From the obtained results there were very highly significant differences between the time of planting and the infestation of insect nymphal stages. However, the population of the adult stages of whitefly on squash plants in the tested regions was obviously highly than that occurred in nymphal stages. The plants sowing in summer 2005 was the best for growing the adult stages of this insect in comparison with other planting times. Summer 2006 come in the second order followed by summer 2004 but the Nili planting time was represent the least preferable time for increasing the whitefly adult stage on squash. The virus ratio infestation was clearly higher when the plants were sowing during summer 2004 but the least preferring time for growing the virus was obviously observed during the period of Nili 2004.

\section{INTRODUCTION}

Whiteflies (Homoptera: Aleyrodidae), are small plant-feeding insects with piercing-sucking mouthparts, and both immature and adult whiteflies feed on the undersides of leaves. Adult whiteflies have the ability to both walk and fly. Bemisia is widely polyphagous, feeding on over 500 species of plants in 74 families. Its hosts include vegetable, field, and ornamental crops. 
Of the important vegetables crops grown in Egypt, Bemisia is a major pest of tomato, peppers, squash, cucumber, beans, eggplant, watermelon, and cabbage. The Egyptian grown field crops of potato, peanut, soybean and cotton are heavily attacked by Bemisia. The ornamental host plants of Bemisia are too numerous to list, but include poinsettia, hibiscus, and chrysanthemum. Bemisia can cause economic damage to plants in several ways. Heavy infestations of adults and their progeny can cause seedling death, or reduction in vigor and yield of older plants, due simply to sap removal. When adult and immature whiteflies feed, they excrete honeydew, a sticky excretory waste that is composed largely of plant sugars. Whitefly, one of the most difficult pests to control, pose a special challenge to gardeners. Whitefly-transmitted cucurbit viruses have been reported from several tropical, subtropical and temperate areas, including America, Asia, and Europe, Brown (1990), Hassan and Duffus (1991), Lot et al.., (1983). Bemisia tabaci was reported to transmit at least five cucurbit viruses, including pumpkin yellow mosaic virus (PYMV) from India, Capoor and Ahmed (1975) lettuce infectious yellow virus (LIYV) from California and Arizona, Brown and Nelson (1986) and Duffus et al., (1986); squash leaf curl virus (SLCV) from the United States, Mexico, and some South American countries, Brown (1990) and cucurbit yellow stunt disorder (CYSDV) from United Arab Emirates, Hassan and Duffus, (1991). So, this study is focused on the following points, study the effect of different times on the population density of whitefly Bemisia argentifolii (Bellows \& Perring) and associated virus infection ratio on squash leaves. However, the effect of inoculation access period (IAP) on the transmission of squash leaf curl virus by the whitefly $B$. argentifolii was also conducted. The study also focused on the relation between nymphs of whitefly $B$. argentifolii population and squash leaf curl virus SLCV ratio infestation.

\section{MATERIALS AND METHODS}

Experiments were carried out on squash plant (Cucubita pepo L. CV. Eskandarani) varity through two hulls. The summer season in the open filed and it was from $25 / 4$ to $15 / 8 / 2004$. In the second season from $12 / 5$ to $25 / 8 / 2005$. Also, $26 / 4$ to $30 / 8 / 2006$ for third season respectively. While the Nili season it was in the glass green houses on the same squash plant varity, it was conducted for two study season from $8 / 9$ to $15 / 12 / 2004$ and form $5 / 10$ to $25 / 1 / 2005$ The sample of plants were taken every two weeks and the area of the field was about $170 \mathrm{~m}^{2}$ on seven replicates and the samples were taken from four corners of the land and also from the center in random way. Though it was taken the first leaf for example from the first plant, the middle from the second and the lower root from the third and soon. It had been counted the complete flies for the silver leaf whitefly visually on 15 plants in the land and it was taken 15 leaves for microscopic Examination in the laboratory for grading, the nymphs number on squash plants for all instars. Also it has been graded, the virus percent approximately in the cultivated area and that by count way. The healthy and infected plants in each replicate 
and calculating the percent for the infected plants approximately and that every tow weeks.

Studying the aquastion acsses period (AAP):

In this study, it has prepared ten cages each cage included ten healthy squash plants. Although it has been taken new infected plant on also it has been covered on it and taken longer group from the healthy flies and put it on that plants. Then taking about 20 flies and put them on the cage number 1 that contain or include tensquash plants and that after 15 minutes. Then after 30 minutes, the 20 flies were put in cage number tow and so on after duplicated time (interval time), all of 20 flies were transferred to the next cages till reaching to cage number ten.

Studying the inoculation accesses period (IAP):

In this study, it has a heady prepared ten cages each cage include ten pots from healthy squash plant. It was placed to infected $B$. argentifolii flies on cage numberone. After that the ten infected flies were put in the next cages each one after interval time reaching the cage number ten after 72 hours.

Studying the number of Bemisia argentifolii adults have the ability to transmit the virus :

It has been taken new infected plant and put large group of $B$. argentifolii healthy files and feed it for 24 hours. It was prepared six cages each cage include five pots from squash plants. One fly was put on the cage number one. However, it was placed three flies on the cage number two, five flies on the cage number three, ten flies on the cage number four, 15 flies on the cage number five and 20 flies were transferred to the cage number six

\title{
RESULTS AND DIUSCUSSION
}

\author{
population density of the silver leaf whitefly Bemisia argentifolii \\ (Insecta:
}

This study was carried out to study the population density of the whitefly $B$. argentifolii in two different planting dates during the two successive seasons 2004 and 2005 on squash plant leaves in Dakahlia Governorate,and the squash curl virus infection on squash leaves was determined.

\section{A-) Summer Plantation:}

Data shown in Table (1) and illustrated in Figure. (1) classify the natural infestation of the whitefly $B$. argentifolii and associated virus infection ratio on squash leaves. The first appearance of the whitefly occurred during the last week of April 2004 but with low adult number and then gradually increased to reach the highest level of infestation during the mid of July of the same season (106 adult individual) and during early of August for nymphal stages (98 individuals). However, the same trend of population was recorded in 2005 summer season but with different numbers recording the peak of abundance during the last week of August for adult stage and during the early of the same month for nymphal stage population

B-) Nili plantation :

The regular inspection of squash leaves throughout the period of experiment revealed that the early infestation was determined during the late 
of April 2004 and continuously increased till reaching to their maximum population level during mid of both July and August (106 and 103 adult stages, respectively. On the other hand the population of whitefly nymphal individuals was slightly lower than that of adult stage recording the peak of abundance during early of August (98 nymphal individuals) during 2004, Table (2) and Fig. (2).However, during 2005 Nili cultivation season, the adult and nymphal infestation of whitefly was obviously denoted that the population was in a gradually increased reaching to their highest level during late of August 140 adult stages and early of August 164 nymphal individuals. Moreover, the virus infection ratio in this study during Nili plantation recorded the highest ratio during early and mid of August 2004 and late of August 2005.

Table (1): Population density of the silver leaf whitefly Bemisia argentifolii (adult and nymphal stage) and virus infection ratio on squash leaves during Summer plantation.

\begin{tabular}{|l|c|c|c|c|c|c|}
\hline \multirow{2}{*}{$\begin{array}{l}\text { Sampling } \\
\text { dates }\end{array}$} & \multicolumn{3}{|c|}{$\mathbf{2 0 0 4}$} & \multicolumn{3}{c|}{2005} \\
\cline { 2 - 7 } & Adults & Nymphs & Virus infection \% & Adults & Nymphs & Virus infection \% \\
\hline $25 / 4$ & 4 & 0 & 0 & - & - & - \\
\hline $9 / 5$ & 19 & 5 & 0 & 19 & 1 & 0 \\
\hline $21 / 5$ & 11 & 5 & 0 & 31 & 15 & 0 \\
\hline $6 / 6$ & 16 & 29 & 26 & 45 & 22 & 12 \\
\hline $20 / 6$ & 62 & 50 & 48 & 55 & 28 & 15 \\
\hline $4 / 7$ & 66 & 43 & 56 & 57 & 34 & 38 \\
\hline $18 / 7$ & 106 & 95 & 62 & 118 & 34 & 46 \\
\hline $1 / 8$ & 71 & 98 & 70 & 88 & 164 & 40 \\
\hline $15 / 8$ & 103 & 45 & 70 & 135 & 95 & 46 \\
\hline $25 / 8$ & - & - & - & 140 & 130 & 70 \\
\hline
\end{tabular}

Effect of the different planting time on the mean number of tested whitefly Bemisia argentifolii stages and virus ratio infestation on squash:

The regular inspection of squash plantations during the different sowing times through the experiment revealed that the following periods Summer 2004, Summer 2005 and Summer 2006 were the preferable time for growing the population of the whitefly nymphs but the Nili 2004 and Nili 2005 were the lowest period for harboring the nymph population. Statistical analysis of given data clearly indicated that there was very highly significant differences between the time of planting and the infestation of insect nymphal stages. However, the population of the adult of whitefly on squash in the tested regions was obviously highly than that occurred in nymphal stages. 
J. Agric. Sci. Mansoura Univ., 34 (6), June, 2009

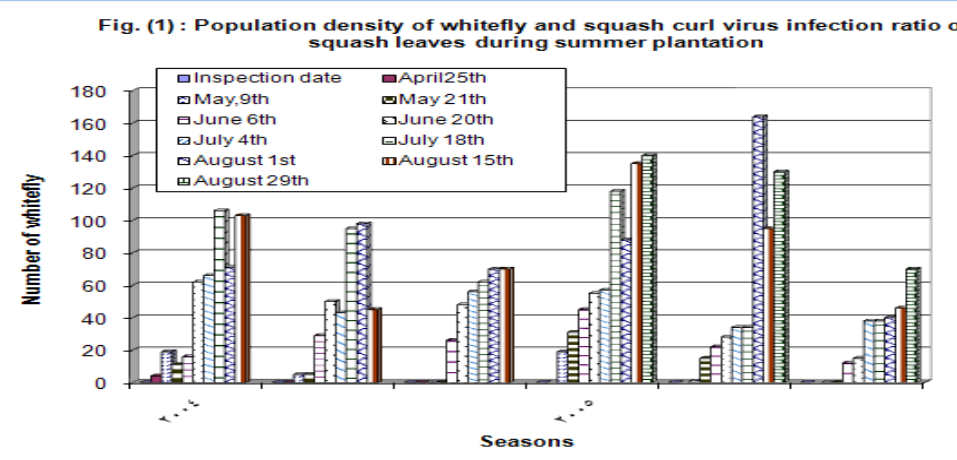

Table (2): Population density of the silver leaf whitefly Bemisia argentifolii (adult and nymphal stage) and virus infection ratio on squash leaves during Nili plantation

\begin{tabular}{|l|c|c|c|c|c|c|}
\hline \multirow{2}{*}{$\begin{array}{c}\text { Sampling } \\
\text { dates }\end{array}$} & \multicolumn{3}{|c|}{$\mathbf{2 0 0 4}$} & \multicolumn{3}{c|}{$\mathbf{2 0 0 5}$} \\
\cline { 2 - 7 } & Adults & Nymphs & $\begin{array}{c}\text { Virus } \\
\text { infection \% }\end{array}$ & Adults & Nymphs & $\begin{array}{c}\text { Virus } \\
\text { infection \% }\end{array}$ \\
\hline $8 / 9$ & 36 & 4 & 0 & - & - & - \\
\hline $22 / 9$ & 34 & 26 & 0.6 & - & - & - \\
\hline $6 / 10$ & 16 & 11 & 14 & 49 & 0 & 0 \\
\hline $20 / 10$ & 26 & 12 & 20 & 57 & 0 & 0 \\
\hline $3 / 11$ & 35 & 30 & 24 & 68 & 4 & 0 \\
\hline $17 / 11$ & 29 & 36 & 7.6 & 55 & 42 & 40 \\
\hline $1 / 12$ & 15 & 22 & 3 & 50 & 34 & 40 \\
\hline $15 / 12$ & 17 & 12 & 3 & 17 & 12 & 40 \\
\hline $29 / 12$ & - & - & - & 7 & 6 & 30 \\
\hline $12 / 1$ & - & - & - & 4 & 0 & 0 \\
\hline $26 / 1 / 05$ & - & - & - & 0 & 0 & 0 \\
\hline
\end{tabular}

Fig. (2) : Population density of whitefly and squash curl virus infection on squash leaves during Nili plantation.

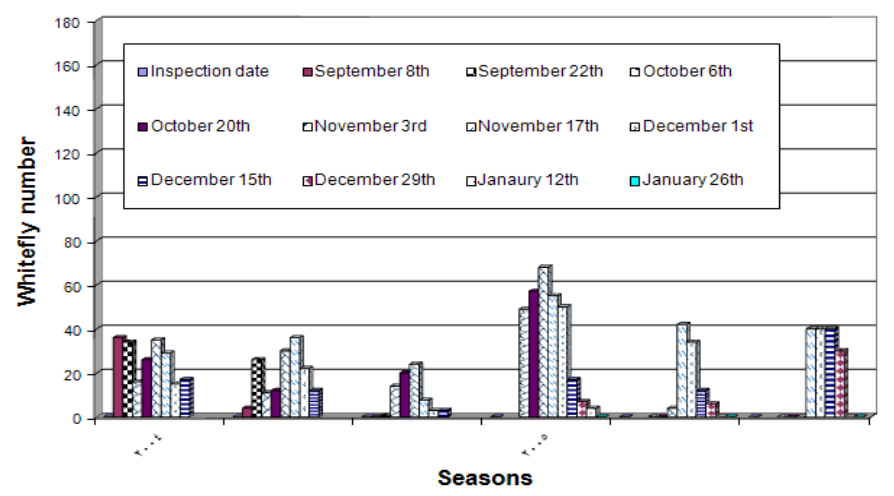

Table (3) denoted that the plants sowing in summer 2005 was the best time for growing the adult stages of this insect in comparison with other planting times. The time of summer 2006 come in the second order followed 
by summer 2004 but the Nili planting time was represent the least preferable time for increasing the whitefly adult stage on squash.On the other hand and as shown in tabulated data in Table (3), the virus ratio infestation was clearly higher when the plants were sowing during summer 2004 time but the least preferring time for growing the virus was obviously demonstrated during the period Nili 2004 growing. The statistical analysis of obtaining data clearly indicated that there were very highly significant difference between the plant sowing in different planting dates and virus ratio infection on squash. Whitefly-transmitted cucurbit viruses have been reported from several tropical, subtropical and temperate areas, including America, Asia, and Europe, Brown (1990), Hassan and Duffus (1991), Lot et al., (1983).Bemisia tabaci was reported to transmit at least five cucurbit viruses, including pumpkin yellow mosaic virus (PYMV) from India, Capoor et al, (1975) lettuce infectious yellow virus (LIYV) from California and Arizona, Brown and Nelson 1986 and Duffus et al., (1986)); squash leaf curl virus (SLCV) from the United States, Mexico, and some South American countries, Brown (1990) and cucurbit yellow stunt disorder (CYSDV) from United Arab Emirates, Hassan and Duffus, (1991). SLCV causes severe systemic stunting and leaf curl in cucurbits. The so-called silver leaf symptom is seen on cucurbits infested by Bemisia tabaci biotype B, but is not associated with SLCV. It has been suggested that it could be due to infection by another virus Bharathan et al., (1992), but it is now generally thought to be induced physiologically by the feeding of biotype $B$ (hence its proposed name $B$. argentifolii).

Table (3): Effect of the different planting time on the mean number of tested white fly Bemisia argentifolii stages and virus ratio infestation on squash

\begin{tabular}{|l|c|c|c|}
\hline \multirow{2}{*}{ Planting time } & \multicolumn{2}{|c|}{ Bemisia argentifolii } & \multirow{2}{*}{ Virus ratio infection \% } \\
\cline { 2 - 3 } & Nymphs & Adults & \\
\hline Summer 2004 & $8.24^{\mathrm{a}}$ & $10.29^{\mathrm{abc}}$ & $36.889^{\mathrm{a}}$ \\
\hline Nili 2004 & $2.343^{\mathrm{b}}$ & $3.34^{\mathrm{c}}$ & $6.586^{\mathrm{c}}$ \\
\hline Summer 2005 & $9.31^{\mathrm{a}}$ & $16.2^{\mathrm{a}}$ & $22.87^{\mathrm{b}}$ \\
\hline Nili 2005 & $2.2^{\mathrm{b}}$ & $6.91^{\mathrm{bc}}$ & $16.66^{\mathrm{b}}$ \\
\hline Summer 2006 & $10.48^{\mathrm{a}}$ & $13.74^{\mathrm{ab}}$ & $24.0^{\mathrm{b}}$ \\
\hline $\begin{array}{l}\text { L. S. D. at } \\
\text { 0.05 level }\end{array}$ & $2.8951^{* \star *}$ & $7.0324^{* *}$ & $6.9999^{* \star *}$ \\
\hline
\end{tabular}

* Significant

Means in the same column followed by the same letters were not significantly, different at $5 \%$ level

The correlation between the different factors affecting on the silver leaf whitefly Bemisia argentifolii populations

Effect of the population density of the whitefly (adults and nymphs) population: The present study an attempt to explore the relation between the population density of the whitefly Bemisia argentifolii (nymphs and adults) and virus ratio infestation, Tables (4,5 and 6$)$. The simple correlation values (r's) helping in detecting any appearance relationship between the population density of the whitefly and the virus ratio infestation. The regression value (b) indicating the average rate of changes in the activity of the white fly (nymphs and adults) due to the unit change in the virus ratio infestation. 
The relation between the population density of Bemisia argentifolii adult and nymphs:

Table (4) shows the changes in the population of the whitefly (nymphs) in the change in the population of adults. The analysis shows apositive and lower significant relation in summer 2004 and a positive and very highly significant relation in Nili 2004 and summer 2005. However the relation between the different individuals nymph and adult stage of whitefly was non-significantly.

Table (4): The correlation between nymphs and adult number of the silver leaf white fly Bemisia argentifolii .

\begin{tabular}{|l|c|c|c|}
\hline Planting dates & $\begin{array}{c}\text { Correlation (r) } \\
\text { S. E. }\end{array}$ & $\begin{array}{c}\text { Slope (b) } \\
\text { S. E. }\end{array}$ & $\begin{array}{c}\text { (a) } \\
\text { p }\end{array}$ \\
\hline Summer 2004 & 0.3098 & 0.336 & 7.519 \\
& 0.1449 & 0.1572 & $0.0384^{*}$ \\
\hline Nili 2004 & 0.4163 & 0.4980 & 2.1760 \\
& 0.110 & 0.1319 & $3.3788^{\text {*** }}$ \\
\hline Summer 2005 & 0.4235 & 1.474 & 2.467 \\
& 0.1099 & 0.3824 & $2.5903^{\text {*** }}$ \\
\hline Nili 2005 & 0.0415 & 0.0782 & 6.7392 \\
& 0.1524 & 0.2892 & 0.787 n. s. \\
\hline Summer 2006 & 0.2096 & 0.2128 & 11.510 \\
& 0.141 & 0.1433 & 0.144 n. s. \\
\hline
\end{tabular}

${ }^{*}$ Significant ${ }^{* \star \star}$ Very highly significant n. s. non-significant

The relation between nymph numbers of silver leaf whitefly and virus ratio infestation:

Table (5) gives the simple correlation value of the whitefly nymphs population and the ratio of infestation of the virus with their level of significant during the different tested five dates. The correlation values show that for summer 2004, summer 2005 and summer 2006 the relation expressed as very highly significantly positive, while it was negatively insignificant during the period Nili 2005. It can be concluded that the activity of the virus ratio infestation is mostly related to the single effect of whitefly $B$. argentifolii nymphs and to combined action of the tested factors. It seems that the whitefly insect population has a preferred condition for the virus growth.

Table (5): The correlation between nymph number of the silver leaf white fly Bemisia argentifolii and virus ratio infestation

\begin{tabular}{|l|c|c|c|}
\hline Planting dates & $\begin{array}{c}\text { Correlation } \\
\text { S. E. }\end{array}$ & $\begin{array}{c}\text { Slope (b) } \\
\text { S. E. }\end{array}$ & $\begin{array}{c}\text { (a) } \\
\text { p }\end{array}$ \\
\hline Summer 2005 & 0.5938 & 1.124 & 12.4029 \\
& 0.0975 & 0.1847 & $6.0244^{* * *}$ \\
\hline Summer 2006 & 0.7346 & 1.5519 & 7.7361 \\
& 0.0979 & 0.207 & $1.2506^{* * *}$ \\
\hline Nili 2004 & 0.3589 & 1.1187 & 3.9647 \\
& 0.1131 & 0.353 & $0.0023^{* *}$ \\
\hline Summer 2004 & 0.6332 & 1.9587 & 20.7455 \\
& 0.1180 & 0.3650 & $3.0398^{* * *}$ \\
\hline Nili 2005 & 0.6901 & 3.646 & 8.645 \\
& 0.1104 & 0.383 & $1.564^{* * *}$ \\
\hline
\end{tabular}

** Highly significant

*** Very highly significant 
The relation between the population density of adults Bemisia argentifolii adult and virus ratio.

As shown in Table (6), the simple correlation value of the whitefly $B$. argentifolii adults and the ratio of infestation of the virus with their level of significant during the different tested five dates. The correlation values show that for summer 2004, summer 2005, summer 2006 and Nili 20074, the relation expressed as very highly significantly positive, while it was negatively insignificant during the period Nili 2005.

Table (6): The correlation between adult number of white fly Bemisia argentifolii and virus infestation

\begin{tabular}{|l|c|c|c|}
\hline Planting date & $\begin{array}{c}\text { Correlation } \\
\text { S. E. }\end{array}$ & $\begin{array}{c}\text { Slope (b) } \\
\text { S. E. }\end{array}$ & $\begin{array}{c}\text { (a) } \\
\text { p }\end{array}$ \\
\hline Summer 2004 & 0.6888 & 1.964 & 16.6814 \\
& 0.1106 & 0.3152 & $1.692^{* * *}$ \\
\hline Nili 2004 & 0.426 & 1.1089 & 2.8788 \\
& 0.110 & 0.286 & $2.397^{* \star \star}$ \\
\hline Summer 2005 & 0.4367 & 0.237 & 19.0250 \\
& 0.101 & 0.059 & $1.5720^{\star \star \star}$ \\
\hline Nili 2005 & -0.0163 & -0.046 & 16.9832 \\
& 0.1525 & 0.4273 & $0.9151 \mathrm{n} . \mathrm{s}$. \\
\hline Summer 2006 & 0.4715 & 0.981 & 10.519 \\
& 0.127 & 0.265 & $5.4816^{* \star *}$ \\
\hline
\end{tabular}

ry highly significan

n. s. Non-significant

Effect of inoculation access period (IAP) on the transmission of squash leaf curl virus by Bemisia argentifolii:

As shown in Table (7), the inoculation access period on the transmission of squash leaf curl virus significantly affected with time proceeding, where the complete transmission was clearly observed after spending 72 hours, but the exposure time 15 minutes was not affected on the transmission process.

Table (7): Effect of inoculation access period (IAP) on the transmission of squash leaf curl virus by silver leaf whitefly Bemisia argentifolii

\begin{tabular}{|l|c|c|c|c|c|c|c|c|c|c|}
\hline SLCV & \multicolumn{10}{|c|}{ Time exposure for virus transmission } \\
\cline { 2 - 9 } & $\mathbf{1 5} \mathbf{~}$ in & $\mathbf{3 0} \mathbf{~}$ in & $\mathbf{1 ~} \mathbf{h}$ & $\mathbf{2} \mathbf{~}$ & $\mathbf{4} \mathbf{~}$ & $\mathbf{8} \mathbf{~}$ & $\mathbf{1 6} \mathbf{~}$ & $\mathbf{2 4} \mathbf{~}$ & $\mathbf{4 8} \mathbf{~}$ & $\mathbf{7 2} \mathbf{~}$ \\
\hline & $0 / 10$ & $1 / 10$ & $3 / 10$ & $5 / 10$ & $7 / 10$ & $8 / 10$ & $9 / 10$ & $10 / 10$ & $10 / 10$ & $10 / 10$ \\
\hline
\end{tabular}

The transmission of squash leaf curl virus by silver leaf whitefly Bemisia argentifolii :

As shown in Table (8) the data cleared denoted that the number of B.argentifolii insects exposed to virus with acquisition period and the inoculation period was 24 hours significantly affected on the infection ratio. However, no infection with the virus when a single insect exposed to the virus. On the other hand, when the number of exposed insects to virus was ten or more the infection ratio was reached to the maximum level $100 \%$ 
Table (8): Number of silver leaf whitefly Bemisia argentifolii insects that able to transmit the squash curl leaf virus

\begin{tabular}{|l|c|c|c|c|}
\hline No. of insects & $\begin{array}{c}\text { Acquisition } \\
\text { period (h) }\end{array}$ & $\begin{array}{c}\text { Inoculation } \\
\text { period (h) }\end{array}$ & $\begin{array}{c}\text { No of insects able to } \\
\text { transmit the virus }\end{array}$ & $\begin{array}{c}\text { Percentage of } \\
\text { infection }\end{array}$ \\
\hline 1 & 24 & 24 & $0 / 10$ & $0 \%$ \\
\hline 3 & 24 & 24 & $3 / 10$ & $20 \%$ \\
\hline 10 & 24 & 24 & $7 / 10$ & $85 \%$ \\
\hline 15 & 24 & 24 & $10 / 10$ & $100 \%$ \\
\hline 20 & 24 & 24 & $10 / 10$ & $100 \%$ \\
\hline
\end{tabular}

$10=$ the number of infested plants per tested plants

The ratio of infestation with the squash curl leaf virus by the adult stage of silver leaf whitefly Bemisia argentifolii:

As shown in Table (9) the infestation symptoms did not observed in the first and the second day after $B$. argentifolii adult emergence. However, the obtained date denoted that the ratio of symptoms infestation began to increase with the developments of the emerged adults where the ratio of infestation was reached to $20 \%$ after three days of emergence increased to reach to their maximum level $(100 \%)$ after the $8^{\text {th }}$ emergence day. However, no infestation symptoms were appeared for the emergence of $B$. argentifolii adults after the $9^{\text {th }}$ and $10^{\text {th }}$ emergence day. Nearly all of the 1-2 week-old adult females were able to cause an infection in tomato plants following a 48 h IAP, Czosnek et al, (2001).

Table (9): The ratio of infestation with the squash curl leaf virus by the adult stage of silver leaf whitefly Bemisia argentifolii.

\begin{tabular}{|l|c|c|}
\hline Days after adult emergence & Tested plants & Infection symptoms \% \\
\hline $1^{\text {st }}$ day & Insect group No.1 & No symptoms \\
\hline $2^{\text {nd }}$ day & Insect group No.2 & No symptoms \\
\hline $3^{\text {rd }}$ day & Insect group No.3 & 20 \\
\hline $4^{\text {th }}$ day & Insect group No.4 & 30 \\
\hline $5^{\text {th }}$ day & Insect group No.5 & 70 \\
\hline $6^{\text {th }}$ day & Insect group No.6 & 70 \\
\hline $7^{\text {th }}$ day & Insect group No.7 & 100 \\
\hline $8^{\text {th }}$ day & Insect group No.8 & No symptoms \\
\hline $9^{\text {th }}$ day & Insect group No.9 & No symptoms \\
\hline $10^{\text {th }}$ day & Insect group No.10 & \\
\hline
\end{tabular}

In comparison, only about $20 \%$ of the males of the same age were able to produce infected plants. Inoculation capacity decreased with the age of the insects; $60 \%$ of the three week-old females were able to cause an 
Abu El-Nagga, A. M. et al.

infection in plants, whereas no infected plants were obtained following inoculation by males of the same age. Only $20 \%$ of the six week-old females were able to infect tomato plants. Although the rate of TYLCV translocation is similar in males and females, it is possible that different amounts of virus translocate in the two genders Ghanim et al., (2001), and the putative begomoviruse receptors in males and females may differ. To determine percentages of tomato yellow leaf curl virus infection on tomato varities at the different treatments, two inspections were carried out, Dawood et al., (1999). First inspection was conducted about 30 days after transplanting, where the second one was carried after 60 days. The results indicated that the occurrence of TYLCV infection was coincide with the mean number of whitefly $B$. tabaci adult while the lowest infection percentage occurrence were recorded in case of the lowest $B$. tabaci adult infestation.

\section{REFERENCES}

Bharathan, N.; K.R. Narayanan and R.T. McMillan (1992). Characteristics of sweet potato whitefly-mediated silver leaf syndrome and associated double-stranded RNA in squash. Phytopathology 82, 136-141.

Brown, J. K. (1990). An update on the whitefly transmitted geminiviruses in the Americas and the Caribbean Basin. FAO Plant Prot.Bull. 39:5-23.

Brown, J. K., and M. R Nelson (1986). Whitefly-borne viruses of melons and lettuce in Arizona. Phytopathology 76:236-239

Capoor, S. P., and R. U. Ahmed (1975). Yellow Vein Mosaic disease of field pumpkin and its relationship with the vector, Bemisia tabaci. Indian Phytopathology. 28:241-246

Czosnek, H.; M. Ghanim and M. Ghanim (2001). The circulative path way of begomoviruse in the whitefly vector Bemisia tabaci-insights from studies with tomato yellow leaf curl virus.Ann.Appl.Biol.,140:215 - 231.

Dawood, M. Z.; K. K. El-Rafie; S.S. Aly and M. F. Hyder (1999). Susceptibility of some tomato varities and hybrids to whitefly Bemisia tabaci (Genn.) infestation in relation to rate of TYLCV infection and the yield. Egypt. J. Agric. Res., 77 (3): 1059 -1064.

Duffus, J. E.; R, L. Larsen and H. Y. Liu (1986). Lettuce infectious yellow virus. A new type of whitefly transmitted virus. Phytopathology 76:97100.

Ghanim, M.; S. Morin and H. Czosnek (2001). Rate of Tomato yellow leaf curl virus (TYLCV) translocation in the circulative transmission pathway of its vector, the whitefly Bemisia tabaci. Phytopathology 91:188-196.

Hassan, A. A., and J. E. Duffus (1991). A review of a yellowing and stunting disorder of cucurbits in the United Arab Emirates. Emir.J. Agric. Sci. 2:1-16.

Lot, H., B, Delecolle and H. Lecog (1983). A whitefly transmitted virus causing musk melon yellows in France. Acta Hortic. 12:175-182. 
علاقة الكثافة العدديـة للاببابة البيضـاء فوانتشار فيروس تجعد و التفاف اوراق الكوسة على نباتـات الكوسـة

$$
\begin{aligned}
& \text { فى مصر مدر }
\end{aligned}
$$

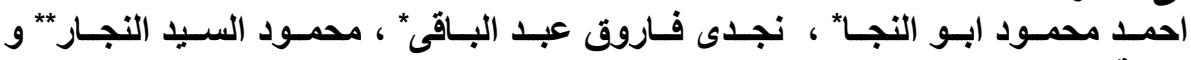

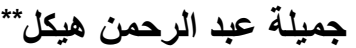

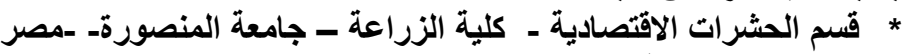

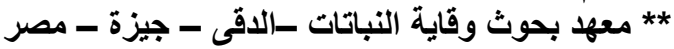

يعتبر الذباب الابيض من الحشرات ذات الفم الثاقب الماص و التى تتخذى على عو ائل نباتية كثيرة

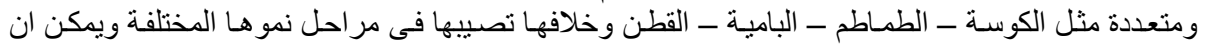

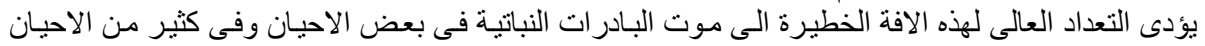

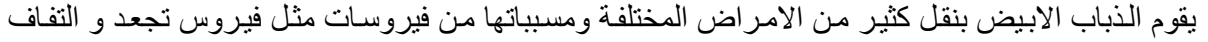

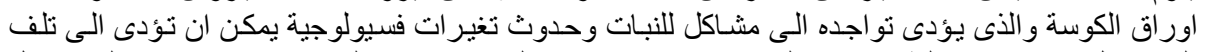

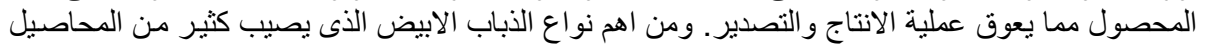

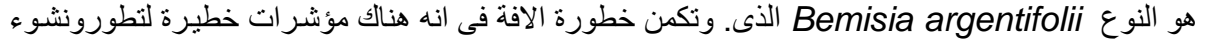

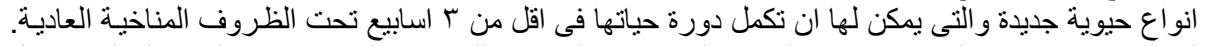

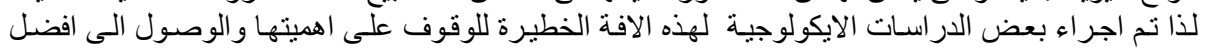

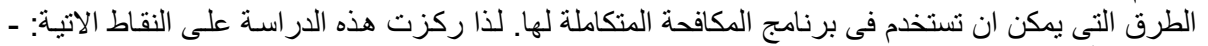

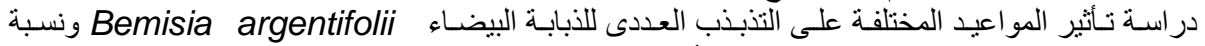

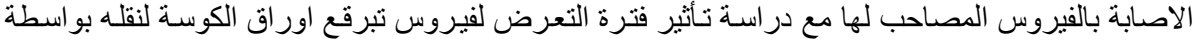

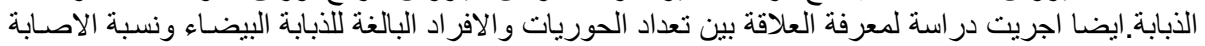

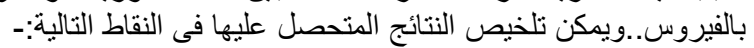

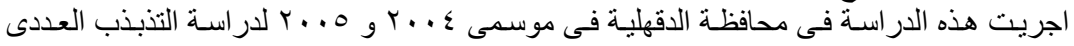
للاببابة البيضـاء Bemisia argentifolii على اوراق الكوسة فى اكثر من عروة زراعية (العروة الصيفية

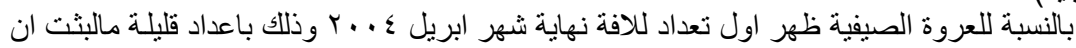

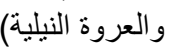

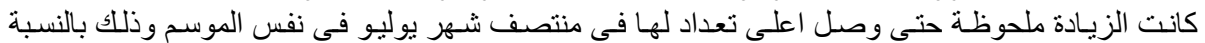

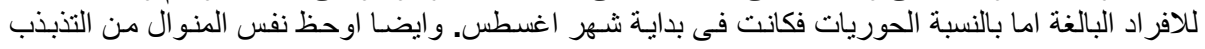

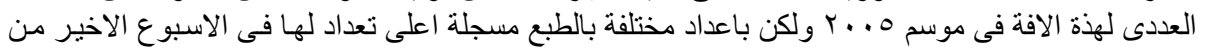

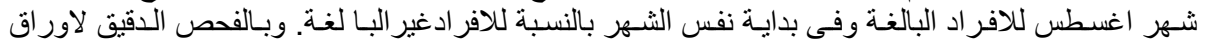

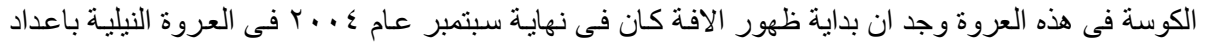

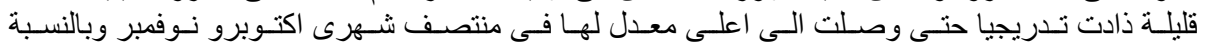

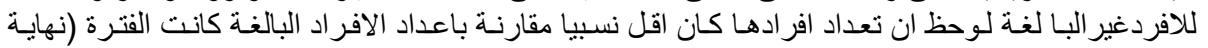

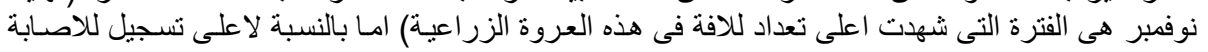

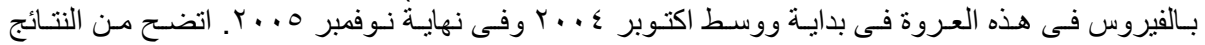

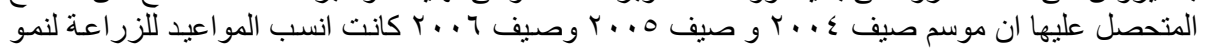

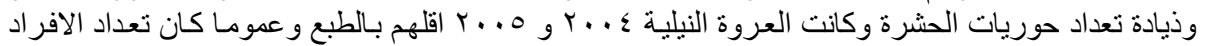

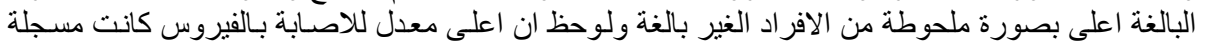

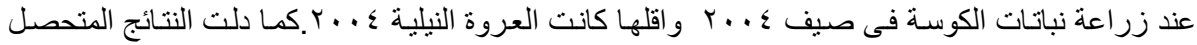

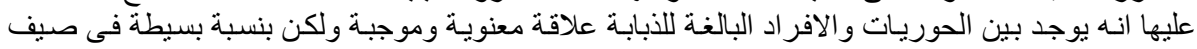

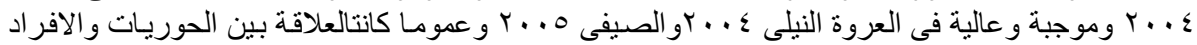

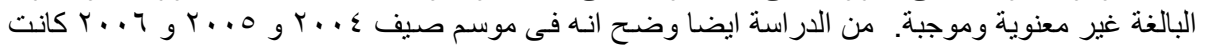

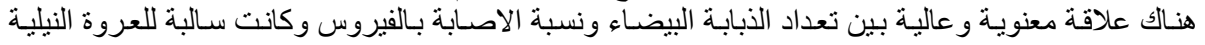

